\title{
Rolled Winter Rye and Hairy Vetch Cover Crops Lower Weed Density but Reduce Vegetable Yields in No-tillage Organic Production
}

\author{
Matthew J. Leavitt, Craig C. Sheaffer ${ }^{1}$, and Donald L. Wyse \\ Department of Agronomy, University of Minnesota, 1991 Upper Buford \\ Circle, 411 Borlaug Hall, St. Paul, MN 55108-6026
}

\author{
Deborah L. Allan \\ Department of Soil, Water and Climate, University of Minnesota, 1991 Upper \\ Buford Circle, 439 Borlaug Hall, St. Paul, MN 55108-6028
}

\begin{abstract}
Additional index words. roller-crimper, tomato, zucchini, bell pepper, reduced tillage, cover crop, cool climate, winter seeded, Solanum lycopersicum, Cucurbita pepo, Capsicum annuum, Secale cereale, Vicia villosa Roth
\end{abstract}

\begin{abstract}
Winter annual cover crops, winter rye (Secale cereale L.) and hairy vetch (Vicia villosa Roth), can reduce weed density and build soil quality in organic production systems. There is interest in integrating cover crops and reduced tillage with organic vegetable production, but few studies have been conducted in regions with short growing seasons and cool soils such as the upper Midwest. We evaluated no-tillage production of tomato (Solanum lycopersicum L.), zucchini (Cucurbita pepo L.), and bell pepper (Capsicum annuum L.) planted into winter rye, hairy vetch, and a winter rye/hairy vetch (WR/HV) mixture that were mechanically suppressed with a roller-crimper at two locations in Minnesota. Average marketable yields of tomato, zucchini, and bell pepper in the rolled cover crops were reduced $89 \%, 77 \%$, and $92 \%$ in 2008 and $65 \%, 41 \%$, and $\mathbf{7 9 \%}$ in 2009, respectively, compared with a no-cover control. Winter rye and the WR/ HV mixture reduced average annual weed density at St. Paul by $96 \%$ for 8 to 10 weeks after rolling (WAR) and hairy vetch mulch reduced weeds $80 \%$ for 2 to 8 WAR, whereas at Lamberton, there was no consistent effect of cover treatments on weed populations. Winter rye and the WR/HV mixture had higher average residue biomass (5.3 and 5.7 $\mathrm{Mg} \cdot \mathrm{ha}^{-1}$, respectively) than hairy vetch $\left(3.0 \mathrm{Mg} \cdot \mathrm{ha}^{-1}\right)$ throughout the season. Soil growing degree-days (SGDD) were lower in cover crop treatments compared with the no-cover control, which could have delayed early vegetable growth and contributed to reduced yields. All cover crop mulches were associated with low levels of soil nitrogen $(N)$ (less than $10 \mathrm{mg} \cdot \mathrm{kg}^{-1} \mathrm{~N}$ ) in the upper $15 \mathrm{~cm}$. Rolled winter annual cover crops show promise for controlling annual weeds in organic no-tillage systems, but additional research is needed on methods to increase vegetable crop yields in rolled cover crops.
\end{abstract}

Fruit and vegetable production continue to dominate the organic market in the United States, constituting over $37 \%$ of the nearly \$25 billion in total sales (ERS-USDA. C. Greene, 2009). With continued increases in the percent growth of the organic market since 1990 , there is enormous potential for growers to reap the benefits of this trend (Dimitri and Greene, 2002). However, there remain significant production limitations to profitable organic

Received for publication on 26 Aug. 2010. Accepted for publication 29 Nov. 2010.

We thank Albert Markhart and Greg Reynolds for their guidance in developing this project. Thank you to Lee Klossner, Joshua Larson, and Kevin Betts for their help in fieldwork and data collection. Mention of a trademark, proprietary product, or vendor does not constitute a guarantee or warranty of the product by the University of Minnesota and does not imply its approval to the exclusion of other products or vendors that may be suitable.

${ }^{1}$ To whom reprint requests should be addressed; e-mailsheaf001@umn.edu. production in some regions. Weed management is often identified as a key challenge of growing crops organically (Clark et al., 1997; Riemens et al., 2007). A comprehensive survey of organic producers from around the United States found that weed management and associated labor costs were the top problems experienced by respondents (MDA M. Moynihan, 2007; Organic Farming Research Foundation, 2004). Weed management in organic systems often relies on mechanical cultivation and tillage that can be detrimental to soil health and quality (Kuratomi et al., 2004).

Among organic producers, there is growing interest in using winter annual cover crops with no-tillage systems to manage weeds and reduce reliance on mechanical cultivation. Notillage organic systems rely on cover crops to replace the use of herbicides, which are widely used in conventional reduced tillage (Singer, 2008; Triplett and Dick, 2008; Yenish et al., 1996). These cover crop systems can reduce weed populations (Clark and Panciera, 2002); preserve soil structure, soil quality, and soil moisture (Dabney, 1998; Lamarca, 1996; Schonbeck and Evanylo, 1998; Villamil et al., 2006); and have potential to produce yields, which are equivalent to traditional production methods (Hoyt, 1999). Improvements and developments in no-tillage seeders, vegetable transplanters, and machinery to control highresidue cover crops have increased the efficacy of this system in recent years (Hoyt et al., 1994; Morse, 1999). However, mechanical weed control remains a challenge in no-tillage, high-residue systems (Teasdale et al., 2007). Moreover, high-residue cover crops can affect growth of some crops by keeping soil temperatures low (Hoyt, 1999; Teasdale and Daughtry, 1993; Teasdale and Mohler, 1993) and immobilizing soil N (Hoyt and Mikkelson, 1991), two concerns in upper Midwestern states with short growing seasons and cooler climates. Low soil temperatures can slow the maturity rate of vegetable crops and delay the timing of harvest, a key financial consideration in a fresh-market operation. Appropriate cover crops for northern climates can depend on rotations, machinery, and desired cash crops, but much research has been focused on the use of winter rye (Secale cereale L.) (Singer, 2008; Snapp et al., 2005) and hairy vetch (Vicia villosa Roth) (Sustainable Agriculture Network, 1998).

Winter rye accumulates significant biomass in varied climates, can scavenge residual soil $\mathrm{N}$ and reduce nitrate leaching (Feyereisen et al., 2006; Ranells and Wagger, 1997; Wyland et al., 1996), and provides both physical (Teasdale and Mohler, 1993) and allelopathic (Barnes and Putnam, 1983) impediments to weed emergence. Walters and Young (2008) found that a dense stand of winter rye residues controlled $\approx 80 \%$ of common annual weeds; similar results were reported elsewhere (Liebl et al., 1992; Masiunas, 2006; Teasdale et al., 1991). Vegetable yield responses to winter rye residues varied depending on the amount of mulch biomass and the vegetable species. NeSmith et al. (1994) found similar yields of summer squash (Cucurbita pepo L.) when established without tillage into winter rye residues compared with conventional production with no cover, but Walters and Young (2008) observed significant zucchini (Cucurbita pepo L.) stunting and reduced yields of $20 \%$ to $50 \%$ when planted into winter rye residues. Some researchers have reported positive or equivalent yield responses with tomatoes (Solanum lycopersicum L.) (Abdul-Baki et al., 1996; Madden et al., 2004; Smeda and Weller, 1996), cabbage (Brassica oleracea L.) (Borowy, 2004), and broccoli (Brassica oleracea var. botrytis) (Morse, 1995) transplanted into winter rye and other grass covers. Others have reported reduced yields of bell pepper (Capsicum annuum L.) (Díaz-Pérez et al., 2008), broccoli, cabbage, sweet corn (Zea mays convar. saccharata var. rugosa), and tomato (Madden et al., 2004; Roberts and Cartwright, 1991) when vegetables were established without tillage into winter rye plots compared with no-cover controls.

Hairy vetch has superior winter-hardiness compared with other winter annual legumes (Brandsæter and Netland, 1999), suppresses 
weeds (Hoffman et al., 1993, Teasdale et al., 1991), produces rapid spring biomass, and fixes an average of $123 \mathrm{~kg} \mathrm{~N} / \mathrm{ha}$ under ideal soil conditions (Sarrantonio, 1994; Sustainable Agriculture Network, 1998). Yield responses to hairy vetch residues have generally been positive. In a 6-year study, tomatoes transplanted into killed hairy vetch mulch yielded more than when planted into black polyethylene mulch and bare soil (Abdul-Baki et al., 1996; Teasdale and Abdul-Baki, 1995). Mills et al. (2002) corroborated those results, but under drought conditions, tomato yields with black plastic were superior to those with hairy vetch.

The many mechanical methods explored for killing cover crops in no-tillage, highresidue systems have been well reviewed (Creamer and Dabney, 2002). Roller-crimpers, used extensively in Latin America, have been tested in the United States and have shown promise as an effective tool for no-tillage cover crop systems. The roller-crimper is a drum roller with horizontal or chevron welded blunt metal strips that crushes and crimps the stems of the cover crop without chopping (Ashford and Reeves, 2003). Creamer and Dabney (2002) found that rolling was more efficient, faster, and left more persistent mulch than mowing alone, thereby controlling weeds for a longer period of time. A roller-crimper leaves uniformly distributed residue, concurrently lowering weed density by increasing layering in the mulch and reducing the available space between those layers (Teasdale and Mohler, 2000). Moreover, the roller-crimper lays mulch down in a flat, uniform direction, which facilitates better soil contact for planting machinery. Highresidue, no-tillage vegetable systems controlled with a roller-crimper respond well to the use of transplants as opposed to direct seeding of vegetable crops (Morse, 1999). No-tillage high-residue systems need more evaluation for organic vegetable production in cool, northern climates (Phatak et al., 2002). Our objective was to determine the effect of hairy vetch, winter rye, and a WR/HV mixture that have been rolled-crimped on establishment and yield of tomato, bell pepper, and zucchini. In addition, we evaluated the impact of rolledcrimped winter annual cover crops on soil properties, weed populations, and mulch characteristics.

\section{Methods and Materials}

Rolled cover crop experiments were conducted at the University of Minnesota, St. Paul, and at the Southwest Research and Outreach Center, Lamberton, MN, in 2008 and 2009. Air temperature and precipitation data for each site and year (Minnesota Climatology Working Group, 2009) are discussed in the "Results." The soil at St. Paul is a well-drained Waukegan silt loam (fine-silty over sandy, mixed mesic Typic Hapludoll) and the soil at Lamberton is a Normania-Ves complex loam (fine-loamy, mixed, superactive, mesic Aquic Hapludolls). The experiment at Lamberton was established on certified organic land in 2008 and on first-year transitional organic land in 2009. The St. Paul site was established on first-year transitional organic land in both study years. Previous crops grown on the study sites before seeding the cover crops were spring wheat (Triticum aestivum L.) and mustard (Brassicaceae spp.) at St. Paul and an oat/ alfalfa (Avena sativa L./Medicago sativa L.) mixture at Lamberton.

The experimental design at each location was a randomized complete block with nested arrangement of treatments with four replications (32 total plots). Four whole-plot mulch treatments were the cover crops of winter rye 'Rymin', hairy vetch (VNS), a WR/HV mixture, and a no-cover control. The subplot vegetable treatments were 'Celebrity' tomato, 'California Wonder' bell pepper, and 'Anton' or 'Raven' zucchini. At St. Paul and Lamberton, 'Anton' zucchini was planted in 2008 and 'Raven' was planted in 2009 as a result of the unavailability of 'Anton' seed. These species and cultivars were chosen in consultation with organic growers to simulate a diverse, organic vegetable operation. Whole plot size was $38.7 \times 48.8 \mathrm{~m}$ at St. Paul and Lamberton. The vegetable subplots were $2.4 \times 9.1 \mathrm{~m}$. Between each treatment replication, there was a $1.5-\mathrm{m}$ wide alley planted with winter rye at St. Paul and tilled bare soil at Lamberton.

Winter rye, hairy vetch, and the WR/HV mixture were drilled in $20-\mathrm{cm}$ row spacing at a depth of $2.5 \mathrm{~cm}$ into a seedbed prepared with a chisel plow and field cultivator. Cover crops for the 2008 study year were planted on 10 Sept. 2007 and for the 2009 study on 11 Sept. 2008. Winter rye was seeded at 51 $\mathrm{kg} \cdot \mathrm{ha}^{-1}$ and hairy vetch at $11 \mathrm{~kg} \cdot \mathrm{ha}^{-1}$. For the WR/HV mixture, each species was seeded at the full rate described previously. The seeding rates of both species in the WR/HV mixture were consistent in both years and locations.

The cover crops were rolled - crimped when rye was at anthesis on 16 June 2008 and 1 June 2009 using a roller-crimper designed by I \& J Manufacturing (Gap, PA) and distributed by the Rodale Institute (Kutztown, PA). The growth stage of winter rye was determined by using the Feekes' scale (Feekes, 1941). In instances in which the roller-crimper did not completely kill the cover crops, cover crop regrowth was controlled by manual cutting as needed throughout the season. Hairy vetch regrowth after the rolling event was cut with a weed whip on 13 July and 13 Aug. in 2008. In 2009, hairy vetch regrowth was cut on 24 June; 8 , 15, and 22 July; 6, 17, and 27 Aug.; and 14 Sept. The no-cover control plots were rototilled before rolling the cover crops.

Vegetable subplots consisted of three rows of $9 \mathrm{~m}$ length at spacing of $90 \mathrm{~cm}$ between rows. Tomato and zucchini were planted 90 $\mathrm{cm}$ apart within the rows, and bell pepper was planted $50 \mathrm{~cm}$ apart within rows. Certified organic transplants of tomatoes and bell pepper were purchased to ensure uniformity of plants put into the field (Plug Connection, Vista, CA). The transplants were seeded and grown for 2 to 3 weeks at the Plug Connection's certified organic facilities and were shipped in 288-cell trays. The transplants were potted up once they arrived in 60-cell flats (cell size $4 \times 5 \times 5.5 \mathrm{~cm}$ ) filled with a certified organic potting mixture, Cowsmo \#1 (Cochrane, WI) (33.5\% peat:33.5\% compost: $16 \%$ sand: $16 \%$ perlite: $1 \%$ fertilizer), $\approx 3$ weeks before planting in the field. Transplants were grown in a greenhouse at 21.1 ${ }^{\circ} \mathrm{C}$ (day) and $15.5{ }^{\circ} \mathrm{C}$ (night). Plants were hardened off for $4 \mathrm{~d}$ before planting. Precipitation was minimal and outside temperatures during that time averaged $19.7^{\circ} \mathrm{C}$ in 2008 and $18.2^{\circ} \mathrm{C}$ in 2009 . Certified organic zucchini seed was planted in 60 -cell flats in the organic potting mix $\approx 3$ weeks before planting. Immediately after rolling the mulch, the transplants were manually planted by hand-digging, inserting the plant into the cover crop residue, and then replacing the mulch. The transplants were manually watered immediately after planting and then three times weekly in 2008 . Each plant received $\approx 4 \mathrm{~cm}$ of water during each watering event. A drip irrigation system was installed in 2009 with drip lines laid on the mulches and bare soil next to the plants. In 2009, plots were irrigated every other day to avoid water stress with the irrigation system delivering $\approx 2 \mathrm{~cm}$ of water at each irrigation event. Vegetable transplants that did not survive were replaced at 2 weeks and again at 4 WAR. Organic pest control was used at both St. Paul and Lamberton as pests became visible in routine field scouting. In 2008 and 2009, squash bugs (Anasa tristis DeGeer) and cucumber beetles (Acalymma vittatum Fabricius) occurred at St. Paul and Lamberton. Pyrethrin insecticide (Pyganic, MGK, Minneapolis, MN) was applied at $0.18 \mathrm{~L} \cdot \mathrm{ha}^{-1}$ for insect control after field scouting.

Plant data. Vegetable stand establishment was determined in the center row of each vegetable subplot by counting dead or dying plants and survivors at 2 and 4 weeks after cover crop rolling. Harvest of vegetables started with the maturity of the first ripe fruit and continued until plants died from frost damage in the fall. The middle row of the three rows in each cover crop treatment was harvested. Tomatoes were harvested weekly, weighed, and separated by size and marketability using the U.S. Standards for Grades (USDA, 1997a). Tomatoes in Grades 0 and 1 were accepted as marketable and tomatoes in Grades 2 and 3 were culled. Zucchini was harvested three times weekly and visually rated for overall appearance (USDA, 1997b; Walters and Young, 2008). The fruit was separated into marketable (10.2 to $20.3 \mathrm{~cm}$ in length) and oversized/cull (greater than $20.3 \mathrm{~cm}$, misshapen, off-color, or damaged fruit). Peppers were harvested once at the end of the season and were separated into marketable $(6.4 \mathrm{~cm}$ or greater in diameter and length) and non-marketable (less than 6.4 $\mathrm{cm}$ in diameter and length, decaying, misshapen, or discolored fruit) (USDA, 2005).

Cover crop data. Cover crop control resulting from the roller-crimper was assessed visually at 2,4 , and 8 WAR on a scale of $0 \%$ (no cover crop killed) to $100 \%$ (cover crop completely killed) (Ashford and Reeves, 2003; 
Frans et al., 1986). The dry mass of the rolled winter rye, hairy vetch, and WR/HV mixture treatments were determined by sampling four $0.1-\mathrm{m}^{2}$ quadrants from the interrow areas between vegetable rows to the soil surface 2 to 4 WAR (early season), 7 to 8 WAR (midseason), and 13 to 14 WAR (late season). All four subsamples were combined and averaged over all of the vegetable subplots. Bare spots left after sample collection were replaced with mulch from border areas to maintain the integrity of the treatments and were not sampled further. Samples were dried in a forced-air oven at $150{ }^{\circ} \mathrm{C}$ for $4 \mathrm{~d}$ and weighed.

Weed data. Weed populations were determined by counting and identifying weeds at $2,4,8$, and 16 WAR in two randomly distributed $0.25-\mathrm{m}^{2}$ quadrants within each cover crop treatment. Weeds were identified and separated into perennial and annual categories. Annual and perennial weeds were removed from the plots by hand after weed densities were recorded. Plots were weeded and annual weeds removed every 2 weeks, whereas perennial weeds were removed as necessary throughout the growing season. In 2008, all perennial weeds in cover crop plots were cut with a weed whip and pulled on 13 July and 13 Aug. (4 and 8 WAR). In 2009, all perennial weeds in cover crop plots were cut and pulled on 24 June 24; 8, 15, and 22 July; 6, 17, and 27 Aug.; and 14 Sept. (3, 5, $6,8,9,10,12,14$ WAR).

Soil sampling and fertilization. Sixteen soil cores were taken across the whole research field at all locations in the fall of 2007 and 2008 at 0 to $15 \mathrm{~cm}, 15$ to $30.5 \mathrm{~cm}$, and 30.5 to $61 \mathrm{~cm}$. Samples were combined according to depth and then subsampled. Soil was analyzed for extractable phosphorus (P), potassium $(\mathrm{K})$, and organic matter in the top $15 \mathrm{~cm}$ and extractable nitrate and ammonium at all depths (NDSU, 2010). Extractable $\mathrm{NO}_{3}-\mathrm{N}$ and ammonium $\left[\mathrm{NH}_{4}\right]-\mathrm{N}$ were determined from four 0 - to $15-\mathrm{cm}$ samples from the interrow areas of each cover crop treatment at St. Paul in 2007 and 2008. Samples were extracted with $2 \mathrm{M} \mathrm{KCl}$ and analyzed by flow injection according to the methods of Sechtig (1992) and Switala (1993). Subsamples were air-dried in paper bags at 20 to 25 ${ }^{\circ} \mathrm{C}$ for 3 weeks and then used in the extraction procedure. Initial soil test levels at St. Paul measured $586 \mathrm{mg} \cdot \mathrm{kg}^{-1} \mathrm{P}, 910 \mathrm{mg} \cdot \mathrm{kg}^{-1} \mathrm{~K}$, and $5 \%$ organic matter in 2008 and $555 \mathrm{mg} \cdot \mathrm{kg}^{-1}$ $\mathrm{P}, 758 \mathrm{mg} \cdot \mathrm{kg}^{-1} \mathrm{~K}$, and $4.5 \%$ organic matter in 2009. Initial nutrient levels at Lamberton measured $20 \mathrm{mg} \cdot \mathrm{kg}^{-1} \mathrm{P}, 212 \mathrm{mg} \cdot \mathrm{kg}^{-1} \mathrm{~K}$, and $4.2 \%$ organic matter in 2008 and $24 \mathrm{mg} \cdot \mathrm{kg}^{-1}$ $\mathrm{P}, 180 \mathrm{mg} \cdot \mathrm{kg}^{-1} \mathrm{~K}$, and $3.8 \%$ organic matter in 2009. Studies were conducted on different research fields in 2008 and 2009 at both locations, which accounts for the observed difference of preplant soil nutrients by year.

Soil N levels at St. Paul, before cover crop planting in 2008, were adequate for vegetable crops measuring $24.8 \mathrm{mg} \cdot \mathrm{kg}^{-1} \mathrm{~N}$ from 0 - to $15-\mathrm{cm}$ depth. No preplant soil $\mathrm{N}$ data were available for Lamberton in 2008. Mineral N levels before cover crop planting for the 2009 season were lower in all environments totaling
16.2 and $10.3 \mathrm{mg} \cdot \mathrm{kg}^{-1} \mathrm{~N}$ at St. Paul and Lamberton, respectively. Based on a preplant soil test, $112 \mathrm{~kg} \cdot \mathrm{ha}^{-1} \mathrm{~N}$ was applied at St. Paul as liquefied pig manure $(43 \mathrm{~N}-10.5 \mathrm{P}-22.8 \mathrm{~K})$ at a $\approx 19,000-\mathrm{L} \cdot \mathrm{ha}^{-1}$ rate in early Aug. 2007 before cover crop planting. As a result of high levels of residual N at St. Paul in 2008, plots were not fertilized before cover crop planting. At Lamberton, $108 \mathrm{~kg} \cdot \mathrm{ha}^{-1} \mathrm{~N}$ was applied as composted beef manure $(1.2 \mathrm{~N}-0.5 \mathrm{P}-$ $0.9 \mathrm{~K}$ ) at $9.0 \mathrm{Mg} \cdot \mathrm{ha}^{-1}$ in August before cover planting each year. These initial manure applications were made to ensure adequate nutrient levels for cover crop growth and for early establishment of the vegetable crops. In addition, at each location, liquid fish emulsion fertilizer $(4 \mathrm{~N}-1.7 \mathrm{P}-0.4 \mathrm{~K})$ was applied twice to the crops at a rate of $0.86 \mathrm{~L} \cdot \mathrm{m}^{-2}$ in early and mid July in 2008 and late June and early July in 2009. Composted, dry turkey manure $(8 \mathrm{~N}-0.9 \mathrm{P}-3.3 \mathrm{~K})$ was also applied in mid-July 2009. Turkey manure application in tomato and pepper rows was $10 \mathrm{~g} \cdot \mathrm{m}^{-2}$ per row and each zucchini row received $5 \mathrm{~g} \cdot \mathrm{m}^{-2}$. Fish and turkey fertilizer applications exceeded the normal rates recommended for the respective vegetables because of observed deficiency symptoms of vegetables in our experiment soon after planting in 2009 (Rosen and Eliason, 2005).

Soil temperatures were monitored hourly from mid-May until early November for both study years by burying one data logger (HOBO Pendant; Onset Corporation, Bourne, MA) at a depth of $5.1 \mathrm{~cm}$ in a random interrow location within each cover crop treatment plot. These data were converted to SGDD using the following equation and summarized for early, mid, and late season:

$$
\mathrm{SGDD}=\left\{\left[\left(\mathrm{T}_{\max }+\mathrm{T}_{\min }\right) / 2\right]-10\right\}
$$

A base temperature of $10{ }^{\circ} \mathrm{C}$ and a maximum $\mathrm{T}_{\max }$ of $30{ }^{\circ} \mathrm{C}$ are commonly used for sweet corn and can additionally be used for summer vegetables like tomatoes, zucchini, and bell pepper (Dethier and Vittum, 1967).

Analysis. Data were subjected to analysis of variance (ANOVA) using the PROC Mixed models procedure of SAS (Version 9.2; 2009) (SAS Institute, 2009) to determine the effects of cover crop treatment, location, and study year on vegetable yield, weed density, cover crop biomass, and soil N. Means were separated using Fisher's protected least significant difference $(P \leq 0.05)$. As a result of large differences inherent in comparing yields of varying vegetable crops, each vegetable species was analyzed with ANOVA separately. Data transformations were used as necessary to achieve statistical normality before using SAS. When data were distributed non-normally and could not be amended with normal transformation, data were analyzed with the non-parametric ranked ANOVA procedure. Significant $(P \leq 0.05)$ year $\times$ location $\times$ cover interactions occurred; thus, results are presented by year and location.

An analysis of total labor hours was compiled by recording the amount of hours required to adequately kill the cover crops, keep the no-cover plots weeded, and to perform periodic weeding within the cover crop treatments.

\section{Results}

Air temperature and precipitation. At St. Paul in 2008 and 2009, total season precipitation was $29 \%$ lower than the 30-year average. Monthly precipitation was below normal from May to September in 2008 and from May to July in 2009. Total season precipitation at Lamberton in 2008 and 2009 was 10\% lower than the 30-year average. Precipitation was also deficient in Aug. 2008 and Apr., May, and July 2009. At the time of cover crop rolling and vegetable transplanting in June, precipitation was below normal at St. Paul in 2008 and 2009 and at Lamberton in 2009. Monthly air temperatures were 1 to $2{ }^{\circ} \mathrm{C}$ below the 30 year average March to May at St. Paul and Lamberton in 2008. Lower early-season temperatures in 2008 likely accounted for the later onset of anthesis and blooming of the winter rye and hairy vetch cover crops. Rolling-crimping and vegetable planting was 2 weeks later in 2008 compared with 2009 because of delayed maturity of the cover crops.

Vegetable replacement. Replacement of all vegetables was unaffected by treatments at St. Paul and Lamberton in 2009 and never exceeded $10 \%$ for all vegetables (data not shown). However, at St. Paul in 2008, treatment effects were observed for zucchini where the no-cover control had less replacement $(0 \%)$ than zucchini in winter rye, vetch, and the WR/HV mixture cover crops (average of $25 \%$ ). At Lamberton in 2008, bell peppers had the highest replacement rate in hairy vetch $(64 \%)$ compared with winter rye $(9 \%)$, the WR/HV mixture (9\%), and the no-cover control $(20 \%)$. Likewise, replacement rates of tomato in the hairy vetch (61\%) and the WR/ HV mixture $(37 \%)$ were larger than winter rye $(18 \%)$ and the no-cover control $(13 \%)$. Perennial weed competition at the Lamberton site in both years, in addition to early-season cutworm predation at both St. Paul and Lamberton in 2008 and 2009, likely accounted for high replacement rates and lowered yields.

Vegetable yield. Cover crop treatments consistently reduced marketable yield of all vegetable crops compared with the no-cover control (Table 1). When tomato, zucchini, and bell pepper were grown in rolled winter cover crop residue, average marketable yields were reduced by $89 \%, 77 \%$, and $92 \%$ in 2008 and $65 \%, 41 \%$, and $79 \%$ in 2009 , respectively, compared with those of the no-cover control. Yields of all vegetables were consistently higher in 2009 than 2008, which was likely the result of the increased rates of fertilizer and more uniform application of water from the irrigation system.

Tomato yield. Tomatoes in the no-cover control plots yielded 18.7 and $58.6 \mathrm{Mg} \cdot \mathrm{ha}^{-1}$ marketable fruit in 2008 and 2009 at Lamberton and 17.4 and $44.0 \mathrm{Mg} \cdot \mathrm{ha}^{-1}$ in 2008 and 2009 at St. Paul, respectively. Averaging results for 2008 and 2009 together, winter rye, hairy vetch, and the $\mathrm{WR} / \mathrm{HV}$ mixture 
cover crops reduced tomato yields by $87 \%$, $78 \%$, and $81 \%$ at Lamberton and by $58 \%$, $64 \%$, and $67 \%$ at St. Paul, respectively. At Lamberton in 2008 and 2009 and St. Paul in 2008, yield of marketable tomatoes was similar for the rye, vetch, and WR/HV mixture treatments; but at St. Paul in 2009, tomato yields in the rye treatment were similar to those of the control. This may suggest that the increased rates of organic fertilizer and consistent irrigation had some efficacy in boosting crop yields in the winter rye mulch.

Zucchini yield. Zucchini yields in the nocover control consistently exceeded those of all cover crop treatments and were 18.7 and $58.6 \mathrm{Mg} \cdot \mathrm{ha}^{-1}$ at Lamberton in 2008 and 2009 and 17.4 and $44.0 \mathrm{Mg} \cdot \mathrm{ha}^{-1}$ at St. Paul in 2008 and 2009, respectively. Winter rye, hairy vetch, and WR/HV mixture cover crop treatments lowered average zucchini yields by $75 \%, 57 \%$, and $55 \%$ at Lamberton across both years and by $40 \%, 27 \%$, and $45 \%$ at St. Paul. Although all cover crop treatments reduced yields relative to the no-cover control, cover crop effects on zucchini yield differed by location and year. Zucchini yields were greater in the hairy vetch and WR/HV mixture cover crops than in the winter rye at Lamberton in 2009, whereas zucchini yields in the hairy vetch were greater than those in the WR/HV mixture but similar to the winter rye at St. Paul in 2009. Zucchini in hairy vetch had similar yields as the no-cover control at St. Paul in 2008.

Bell pepper yield. Average bell pepper yield for the no-cover control treatment was 11.6 and $18.1 \mathrm{Mg} \cdot \mathrm{ha}^{-1}$ at Lamberton in 2008 and 2009 and only 2.6 and $7.4 \mathrm{Mg} \cdot \mathrm{ha}^{-1}$ at St. Paul in 2008 and 2009. Peppers in the nocover control had greater yields than the cover crop treatments at Lamberton in both years but similar yields as those in winter rye at St. Paul each year. Pepper plants, particularly in 2008 , did not develop many marketablesized peppers because of delayed maturity resulting from the cover crops. Cover crops had similar effects on pepper yields and reduced average marketable yield at Lamberton by $\approx 90 \%$ in both years, whereas at St. Paul, average yields were lowered by $86 \%$ and $74 \%$ in 2008 and 2009 , respectively.

Weed populations. Weeds at St. Paul were primarily shepherd's purse (Capsella bursapastoris L.), foxtail (Setaria $\mathrm{spp}$.), common lambsquarter (Chenopodium album L.), and redroot pigweed (Amaranthus retroflexus L.). In both years at St. Paul, winter rye and the WR/HV mixture reduced weed populations by at least $96 \%$ for all sampling times compared with the no-cover control except at 16 WAR in 2009 (Table 2). Hairy vetch, although less effective for weed control than winter rye and WR/HV mixture cover crops, also reduced weed populations by a minimum of $80 \%$ compared with the no-cover control at 2 to $8 \mathrm{WAR}$ in both years. However, the effectiveness of hairy vetch for weed control declined at 16 WAR when weed populations were similar to the control. Annual weed populations at Lamberton were mainly foxtail, pigweed, and common purslane (Portulaca

Table 1. Total marketable yield of 'Celebrity' tomato, 'Anton' or 'Raven' zucchini ${ }^{\mathrm{z}}$, and 'California Wonder' bell pepper produced in four rolled cover crop treatments at St. Paul, MN, and Lamberton, MN, in 2008 and 2009.

\begin{tabular}{|c|c|c|c|c|}
\hline \multirow[b]{3}{*}{ Treatment } & \multicolumn{2}{|c|}{ Lamberton } & \multicolumn{2}{|c|}{ St. Paul } \\
\hline & 2008 & 2009 & 2008 & 2009 \\
\hline & \multicolumn{4}{|c|}{$\mathrm{Mg} \cdot \mathrm{ha}^{-1}$} \\
\hline \multicolumn{5}{|l|}{ Tomato } \\
\hline Winter rye & $0.8 \mathrm{~b}^{\mathrm{y}}$ & $12.7 \mathrm{~b}$ & $5.6 \mathrm{~b}$ & $28.6 \mathrm{ab}$ \\
\hline Hairy vetch & $0.1 \mathrm{~b}$ & $22.4 \mathrm{~b}$ & $8.0 \mathrm{~b}$ & $20.8 \mathrm{~b}$ \\
\hline Winter rye + hairy vetch & $0.2 \mathrm{~b}$ & $18.5 \mathrm{~b}$ & $4.9 \mathrm{~b}$ & $21.5 \mathrm{~b}$ \\
\hline No cover (control) & $14.3 \mathrm{a}$ & $86.6 \mathrm{a}$ & $32.5 \mathrm{a}$ & $48.3 \mathrm{a}$ \\
\hline \multicolumn{5}{|l|}{ Zucchini } \\
\hline Winter rye & $1.4 \mathrm{~b}$ & $17.6 \mathrm{c}$ & $5.6 \mathrm{~b}$ & $31.5 \mathrm{bc}$ \\
\hline Hairy vetch & $1.3 \mathrm{~b}$ & $32.2 \mathrm{~b}$ & $8.6 \mathrm{ab}$ & $36.3 \mathrm{~b}$ \\
\hline Winter rye + hairy vetch & $1.7 \mathrm{~b}$ & $32.8 \mathrm{~b}$ & $5.6 \mathrm{~b}$ & $27.9 \mathrm{c}$ \\
\hline No cover (control) & $18.7 \mathrm{a}$ & $58.6 \mathrm{a}$ & $17.4 \mathrm{a}$ & $44.0 \mathrm{a}$ \\
\hline \multicolumn{5}{|l|}{ Bell pepper } \\
\hline Winter rye & $<0.1 \mathrm{~b}$ & $2.6 \mathrm{~b}$ & $0.7 \mathrm{ab}$ & $3.2 \mathrm{ab}$ \\
\hline Hairy vetch & $<0.1 \mathrm{~b}$ & $3.2 \mathrm{~b}$ & $<0.1 \mathrm{c}$ & $0.8 \mathrm{~b}$ \\
\hline Winter rye + hairy vetch & $<0.1 \mathrm{~b}$ & $2.5 \mathrm{~b}$ & $0.4 \mathrm{bc}$ & $2.2 \mathrm{~b}$ \\
\hline No cover (control) & $11.6 \mathrm{a}$ & $18.1 \mathrm{a}$ & $2.6 \mathrm{a}$ & $7.4 \mathrm{a}$ \\
\hline
\end{tabular}

z'Anton' zucchini was planted in 2008 and 'Raven' zucchini was planted in 2009 as a result of unavailability of 'Anton' seed. 'Raven' has similar varietal characteristics as 'Anton'.

${ }^{y}$ Any two means within a column not followed by the same letter are different using Fisher's protected least significant difference $(P \leq 0.05)$. Different vegetables were compared with a separate analysis of variance.

Table 2 . The effects of four rolled cover crop treatments on annual weed density at $2,4,8$, and 16 weeks after rolling (WAR) at St. Paul, MN, and Lamberton, MN, in 2008 and 2009.

\begin{tabular}{|c|c|c|c|c|c|c|c|c|}
\hline & \multicolumn{4}{|c|}{ Lamberton } & \multicolumn{4}{|c|}{ St. Paul } \\
\hline & $2 \mathrm{WAR}$ & $4 \mathrm{WAR}$ & $8 \mathrm{WAR}$ & $16 \mathrm{WAR}$ & $2 \mathrm{WAR}$ & $4 \mathrm{WAR}$ & 8 WAR & $16 \mathrm{WAR}$ \\
\hline Treatment & \multicolumn{8}{|c|}{ No. $/ \mathrm{m}^{2}$} \\
\hline \multicolumn{9}{|l|}{2008} \\
\hline Winter rye & $1 \mathrm{~A}^{\mathrm{z}}$ & $2 \mathrm{~A}$ & $12 \mathrm{~B}$ & $18 \mathrm{~A}$ & $0 \mathrm{~B}$ & $0 \mathrm{~B}$ & $2 \mathrm{~B}$ & $7 \mathrm{~B}$ \\
\hline Hairy vetch & $107 \mathrm{~A}$ & $34 \mathrm{~A}$ & $49 \mathrm{~A}$ & $44 \mathrm{~A}$ & $1 \mathrm{~B}$ & $27 \mathrm{~B}$ & $54 \mathrm{~A}$ & $80 \mathrm{~A}$ \\
\hline $\begin{array}{l}\text { Winter rye + hairy } \\
\text { vetch }\end{array}$ & $10 \mathrm{~A}$ & $5 \mathrm{~A}$ & $20 \mathrm{AB}$ & $25 \mathrm{~A}$ & $0 \mathrm{~B}$ & $2 \mathrm{~B}$ & $1 \mathrm{~B}$ & $8 \mathrm{~B}$ \\
\hline No cover (control) & $6 \mathrm{~A}$ & $-\mathrm{y}$ & $4 \mathrm{~B}$ & $62 \mathrm{~A}$ & $58 \mathrm{~A}$ & $642 \mathrm{~A}$ & $290 \mathrm{~A}$ & $159 \mathrm{~A}$ \\
\hline \multicolumn{9}{|l|}{2009} \\
\hline Winter rye & $0 \mathrm{~B}$ & $31 \mathrm{~A}$ & $18 \mathrm{~A}$ & $16 \mathrm{~A}$ & $0 \mathrm{C}$ & $0 \mathrm{C}$ & $6 \mathrm{BC}$ & $8 \mathrm{~A}$ \\
\hline Hairy vetch & $0 \mathrm{~B}$ & $2 \mathrm{~B}$ & $4 \mathrm{~A}$ & $10 \mathrm{~A}$ & $32 \mathrm{~B}$ & $18 \mathrm{~B}$ & $24 \mathrm{AB}$ & $38 \mathrm{~A}$ \\
\hline $\begin{array}{l}\text { Winter rye + hairy } \\
\text { vetch }\end{array}$ & $0 \mathrm{~B}$ & $1 \mathrm{~B}$ & $2 \mathrm{~A}$ & $8 \mathrm{~A}$ & $0 \mathrm{C}$ & $0 \mathrm{C}$ & $4 \mathrm{C}$ & $10 \mathrm{~A}$ \\
\hline No cover (control) & $30 \mathrm{~A}$ & $4 \mathrm{AB}$ & $11 \mathrm{~A}$ & $12 \mathrm{~A}$ & $178 \mathrm{~A}$ & $98 \mathrm{~A}$ & $225 \mathrm{~A}$ & $26 \mathrm{~A}$ \\
\hline
\end{tabular}

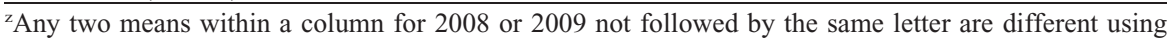
Fisher's protected least significant difference $(P \leq 0.1)$. Different study years were compared with a separate analysis of variance.

${ }^{\mathrm{y}}$ Data were not collected.

oleracea L.). At Lamberton in 2008, there was no difference in weed populations at any date between cover crop treatments and the control. In contrast, in 2009, all cover crop treatments reduced weed populations by $100 \%$ at 2 WAR compared with the no-cover control, but at subsequent samplings, weed populations in the cover crops were not consistently different from the hand weeded, nocover control.

As a result of weed management problems in previous cropping systems at the Lamberton site, perennial weeds were present in 2008 and 2009, but not at the St. Paul site. In 2008 at 2 WAR, Canada thistle (Cirsium arvense L.) and alfalfa (Medicago sativa L.) were initially evenly distributed over treatments with average populations of eight plants $/ \mathrm{m}^{2}$ (Table 3 ). By 16 WAR, perennial weed density was similar for all the cover crop treatments and averaged 38 plants $/ \mathrm{m}^{2}$, which exceeded those of the no-cover control $\left(0\right.$ plants $\left./ \mathrm{m}^{2}\right)$ where extensive hand weeding was necessary. In 2009, perennial weeds, primarily alfalfa, were not present in the no-cover control as a result of mechanical tillage. At 2 WAR, volunteer alfalfa infestation in the winter rye treatment averaged 12 plants $/ \mathrm{m}^{2}$ and exceeded populations in the WR/HV mixture, hairy vetch, and the no-cover control treatments. A variable stand of the winter rye and regrowth of alfalfa played a role in high perennial weed density. Control of perennial weeds also contributed to high labor hours in 2008 and 2009 where regrowth of alfalfa and Canada thistle were weeded on a weekly basis.

Cover crops. The WR/HV mixture population was composed of $4 \%$ hairy vetch at St. Paul in 2008 and 2009 and at Lamberton in 2008 but was $40 \%$ at Lamberton in 2009 . The research field at Lamberton in 2009 was surrounded by a shelterbelt, which reduced winter injury of the hairy vetch and accounted for the higher percentage of hairy vetch in the $\mathrm{WR} / \mathrm{HV}$ mixture. The higher hairy vetch constituent in the WR/HV mixture at the Lamberton site in 2009 did not appear to influence the results of the factors measured and therefore was considered similar to the plots from 2008. 
The roller-crimper was effective at ending the winter rye and $\mathrm{WR} / \mathrm{HV}$ mixture treatments (percent control greater than $85 \%$ ) at 2 , 4 , and 8 WAR at both sites (data not shown). At the time of rolling-crimping, winter rye alone and in the WR/HV mixture was past anthesis, a stage that is recommended for effective killing (Mirsky et al., 2009). However, at this time, the hairy vetch was only at $5 \%$ to $10 \%$ bloom, less mature than the flowering stage when mechanical control is recommended (Mischler et al., 2010). Consequently, hairy vetch was not completely controlled and continued growth after rolling. Hairy vetch termination at 2 WAR was only $33 \%$ and $2 \%$ at Lamberton in 2008 and 2009, respectively, and $13 \%$ and $12 \%$ at St. Paul in 2008 and 2009, respectively. This regrowth was continually controlled by hand clipping and not until 10 WAR were all cover crops terminated.

There was a significant $(P \leq 0.05)$ threeway interaction of year $\times$ location $\times$ cover for biomass yield at both sites. These interactions justified the presentation of residue biomass by year and location. Large variations in biomass yield by location and study year likely accounted for the significant result. Although explanatory factors were not directly measured, it is likely that this large degree of variation occurred from differences in weather, available nutrients, and initial stand establishment.

Dry residue of cover crops throughout the growing season in 2008 and 2009 at St. Paul was greater for the winter rye and the WR/ HV mixture than for hairy vetch. Earlyseason ( 2 to 4 WAR) cover crop biomass averaged for the rye and $\mathrm{WR} / \mathrm{HV}$ mixture treatments was 8.0 and $5.8 \mathrm{Mg} \cdot \mathrm{ha}^{-1}$ in 2008 and 2009 , respectively, whereas hairy vetch yields were 5.0 and $2.9 \mathrm{Mg} \cdot \mathrm{ha}^{-1}$ in 2008 and 2009, respectively (Table 4). There was a significant decrease measured $(P \leq 0.1)$ in biomass over time for the winter rye and hairy vetch in 2008 and for the winter rye in 2009, but the decrease in biomass varied from year to year. In 2008 and 2009, residue biomass for winter rye decreased from early season to late season (13 to 14 WAR) as a result of breakdown and degradation of the mulch over time. Hairy vetch biomass in 2008 also decreased from early season to late season. As a result of vigorous hairy vetch regrowth that occurred in 2009 , despite continued control, hairy vetch residue biomass did not change from early season to midseason. However, by late season in 2009 , vetch had completely died and residual biomass was not measurable.

As occurred at the St. Paul site, cover crop biomass at Lamberton in 2008 was greater for winter rye and the WR/HV mixture than for hairy vetch at all sampling dates and for the early-season sampling in 2009. At mid- and late-season in 2009, cover crops had similar biomass. The rye and WR/HV mixture had relatively constant residual biomass over the season in each year, but hairy vetch biomass increased from early to late season from the regeneration of the cover crop. All biomass yields were notably lower in 2009 than in 2008. High amounts of residue biomass that

Table 3 . The effects of four rolled cover crop treatments on perennial ${ }^{\mathrm{z}}$ weed density at $2,4,8$, and 16 weeks after rolling (WAR) at Lamberton, MN, in 2008w and 2009 .

\begin{tabular}{|c|c|c|c|c|c|c|c|c|}
\hline & \multicolumn{4}{|c|}{2008} & \multicolumn{4}{|c|}{2009} \\
\hline & $2 \mathrm{WAR}$ & $4 \mathrm{WAR}$ & 8 WAR & $16 \mathrm{WAR}$ & $2 \mathrm{WAR}$ & $4 \mathrm{WAR}$ & $8 \mathrm{WAR}$ & $\overline{16 \mathrm{WAR}}$ \\
\hline Treatment & \multicolumn{8}{|c|}{ No. $/ \mathrm{m}^{2}$} \\
\hline Winter rye & $6 \mathrm{~A}^{\mathrm{y}}$ & $16 \mathrm{~A}$ & $14 \mathrm{~A}$ & $42 \mathrm{~A}$ & $12 \mathrm{~A}$ & $12 \mathrm{~A}$ & $31 \mathrm{~A}$ & $20 \mathrm{~A}$ \\
\hline Hairy & $2 \mathrm{~A}$ & $12 \mathrm{~A}$ & $16 \mathrm{~A}$ & $42 \mathrm{~A}$ & $0 \mathrm{~B}$ & $2 \mathrm{~B}$ & $7 \mathrm{BC}$ & $13 \mathrm{AB}$ \\
\hline Winter rye $+h$ & $10 \mathrm{~A}$ & $10 \mathrm{~A}$ & $26 \mathrm{~A}$ & $34 \mathrm{~A}$ & $2 \mathrm{~B}$ & $8 \mathrm{~A}$ & $11 \mathrm{~B}$ & $10 \mathrm{~B}$ \\
\hline No cover (control) & $16 \mathrm{~A}$ & $-^{x}$ & $0 \mathrm{~B}$ & $0 \mathrm{~B}$ & $0 \mathrm{~B}$ & $0 \mathrm{~B}$ & $4 \mathrm{C}$ & $0 \mathrm{C}$ \\
\hline
\end{tabular}

${ }^{2}$ Perennial weeds counted at this location were Canada thistle (Cirsium arvense $\mathrm{L}$.) and alfalfa (Medicago sativa $\mathrm{L}$.).

${ }^{y}$ Any two means within a column not followed by the same letter are different using Fisher's protected least significant difference $(P \leq 0.1)$.

${ }^{x}$ No data collected.

wIn 2008, all perennial weeds in cover crop plots were hand-controlled on 13 July and 13 Aug. (4 and 8 WAR). 'In 2009, all perennial weeds in cover crop plots were hand-controlled on 24 June; 8, 15, and 22 July; 6, 17, and 27 Aug.; and 14 Sept. (3, 5, 6, 8, 9, 10, 12, 14 WAR).

Table 4. Dry residue biomass of three rolled cover crop treatments at early ${ }^{\mathrm{w}}, \mathrm{mid}^{\mathrm{v}}$, and late ${ }^{\mathrm{u}}$ season at St. Paul, MN, and Lamberton, MN, in 2008 and 2009.

\begin{tabular}{|c|c|c|c|c|c|c|}
\hline \multirow[b]{3}{*}{ Treatment } & \multicolumn{3}{|c|}{ Lamberton } & \multicolumn{3}{|c|}{ St. Paul } \\
\hline & Early & Mid & Late & Early & Mid & Late \\
\hline & \multicolumn{6}{|c|}{$\mathrm{Mg} \cdot \mathrm{ha}^{-1}$} \\
\hline 2008 & & & & & & \\
\hline Winter rye & $7.97 \mathrm{a}^{z} \mathrm{~A}^{\mathrm{y}}$ & 9.79 a $\mathrm{A}$ & 8.05 a A & 8.37 a $\mathrm{A}$ & $8.20 \mathrm{a} \mathrm{AB}$ & 6.62 a B \\
\hline Hairy vetch & 1.43 b B & $1.94 \mathrm{~b} \mathrm{~B}$ & $4.84 \mathrm{~b} \mathrm{~A}$ & $5.15 \mathrm{~b} \mathrm{~A}$ & $3.85 \mathrm{c} \mathrm{AB}$ & $2.30 \mathrm{~b} \mathrm{~B}$ \\
\hline $\begin{array}{l}\text { Winter rye + hairy } \\
\text { vetch }\end{array}$ & 8.51 a $\mathrm{A}$ & 9.44 a A & $7.44 \mathrm{ab} A$ & 7.63 a $\mathrm{A}$ & $7.19 \mathrm{~b} \mathrm{~A}$ & 7.15 a A \\
\hline \multicolumn{7}{|l|}{2009} \\
\hline Winter rye & $3.27 \mathrm{~b} \mathrm{~A}$ & 2.26 a A & 3.88 a A & 5.97 a A & $4.71 \mathrm{a} \mathrm{B}$ & $4.80 \mathrm{a} \mathrm{AB}$ \\
\hline Hairy vetch & $2.15 \mathrm{~b} \mathrm{~A}$ & 2.80 a A & 3.72 a A & $2.90 \mathrm{~b} \mathrm{~A}$ & $3.23 \mathrm{~b} \mathrm{~A}$ & $-^{x}$ \\
\hline $\begin{array}{l}\text { Winter rye + hairy } \\
\text { vetch }\end{array}$ & $4.50 \mathrm{a} \mathrm{A}$ & 3.18 a A & 5.23 a A & 5.60 a A & 4.78 a A & 4.62 a A \\
\hline
\end{tabular}

${ }^{\mathrm{z}}$ Any two means within a column for 2008 and 2009 not followed by the same lowercase letter are not different using Fisher's protected least significant difference $(P \leq 0.05)$. Different study years were compared using a separate analysis of variance.

${ }^{y}$ Upper case letters indicate significant least significant difference $(P \leq 0.1)$ within year for comparing individual cover crop treatment means over time.

${ }^{\mathrm{x}}$ Data not collected.

${ }^{w}$ Early season was collected 2 to 4 weeks after rolling (WAR).

"Midseason was collected 7 to 8 WAR.

"Late season was collected 13 to 14 WAR.

changed little over the course of the season, especially in the winter rye and WR/HV mixture plots, likely contributed to the superior weed control in these treatments at both locations in both years.

Soil growing degree-days. Treatment differences in SGDD were detected for early season (date of planting 4 WAR), midseason (date of planting 8 WAR), late season (date of planting 14 WAR) and total season in both study environments in 2008. In a combined analysis over years and locations, year $\times$ cover and year $\times$ location interactions were significant $(P \leq 0.05)$; this suggests that cover crops had varying effects on soil temperature in different study years and locations. The nocover control had higher early- and midseason SGDD than the cover treatments at St. Paul and Lamberton in 2008 and 2009 (Table 5). For late- and total season SGDD in both years, the no-cover control was not consistently different from the cover crop treatments. The hairy vetch cover had more accumulated SGDD than the winter rye and the WR/HV mixture in late season only at St. Paul in 2008.

As a result of rototilling before vegetable planting and the lack of biomass residue on the soil surface, the no-cover control likely captured greater solar radiation and hence had greater SGDD to at least midseason in both environments and years. The hairy vetch often had slightly higher SGDD than both the winter rye and the WR/HV mixture as a result of less residue biomass (Table 4) and more rapid degradation of the cover crop residue (especially at St. Paul in 2008), leaving more exposed soil. In summation, the greater amount of cover crop biomass residue present on the soil surface, the less overall SGDD, which presumably impacted growth and development of vegetable crops.

Extractable nitrogen. Cover crop treatments significantly affected soil $\mathrm{N}$ concentration in plot interrows throughout the season at St. Paul in both years and early in the year at Lamberton in 2009. At the first sampling date in St. Paul (3 July), the nocover control and hairy vetch had the most $\mathrm{N}$ in 2008 (Fig. 1) and 2009 (Fig. 2), whereas the WR/HV mixture and winter rye had the least N. Soil N in the winter rye and WR/HV mixture treatments were similar throughout most of the season and increased until midAugust in 2008 and then declined, whereas hairy vetch soil $\mathrm{N}$ increased from August until the end of the growing season. In 2009, the no-cover control had more available soil $\mathrm{N}$ than all cover crop treatments until the end 
of July. Soil N concentration for the hairy vetch treatment was greater than for the winter rye and $\mathrm{WR} / \mathrm{HV}$ mixture in late June and early July. The large spike in inorganic $\mathrm{N}$ in mid-July in the no-cover control was likely the result of fertilizer in the no-cover control samples; however, no other treatments appeared to respond thusly to fertilizer application. This may suggest possible fertilizer contamination present only in the no-cover control samples. At Lamberton in 2009, no differences in soil $\mathrm{N}$ were detected beyond mid-June when hairy vetch and the no-cover control treatments had greater soil $\mathrm{N}$ concentrations than the winter rye and WR/HV mixture (data not shown). Soil $\mathrm{N}$ levels of all treatments were very low, but no response to fertilizer application was observed.

Soil $\mathrm{N}$ levels $\left(24.8 \mathrm{mg} \cdot \mathrm{kg}^{-1} \mathrm{~N}\right.$ from 0 - to 15-cm depth) at St. Paul, before cover crop planting in 2008, were considered adequate for vegetable crops production. Additional fertilization was added during early growth and flowering to ensure optimum production of vegetable crops in 2008. In 2009, observed nutrient deficiency symptoms prompted increased rates of fertilization. Mineral $\mathrm{N}$ levels before cover crop planting for the 2009 season were lower in all environments totaling 16.2 and $10.3 \mathrm{mg} \cdot \mathrm{kg}^{-1} \mathrm{~N}$ at St. Paul and Lamberton, respectively. This may be the result of different crop histories on those fields before the cover crop experiments. Judging from the low mineral $\mathrm{N}$ levels observed after vegetable planting in all treatments (less than $10 \mathrm{mg} \cdot \mathrm{kg}^{-1}$ $\mathrm{N})$, a large amount of $\mathrm{N}$ was either taken up by growing cover crops and/or leached from the soil; when combined with soil temperature reduction, this may have led to lower yields in cover crops compared with the no-cover control.

Labor. Total person hours for hand weeding the no-cover control plots and controlling the regrowth of non-killed cover crops was

Table 5. Effects of four rolled cover crop treatments on early $\mathrm{y}^{\mathrm{z}}$, $\mathrm{mid}^{\mathrm{y}}$, late ${ }^{\mathrm{x}}$, and total ${ }^{\mathrm{w}}$ season soil growing degree-days (SGDD; base $10^{\circ} \mathrm{C}$ ) at St. Paul, MN, and Lamberton, MN, in 2008 and 2009.

\begin{tabular}{|c|c|c|c|c|c|c|c|c|}
\hline \multirow[b]{3}{*}{ Trostmont } & \multicolumn{4}{|c|}{ St. Paul } & \multicolumn{4}{|c|}{ Lamberton } \\
\hline & Early & Mid & Late & Total & $\begin{array}{l}\text { Early } \\
\end{array}$ & Mid & Late & Total \\
\hline & \multicolumn{8}{|c|}{ SGDD } \\
\hline \multicolumn{9}{|l|}{2008} \\
\hline Winter rye & $530 \mathrm{c}^{\mathrm{v}}$ & $1102 \mathrm{c}$ & $1688 \mathrm{c}$ & $1781 \mathrm{~b}$ & $607 \mathrm{~b}$ & $1221 \mathrm{~b}$ & $1834 \mathrm{bc}$ & $1935 \mathrm{~b}$ \\
\hline Hairy vetch & $649 \mathrm{~b}$ & $1300 \mathrm{~b}$ & $2021 \mathrm{~b}$ & $2152 \mathrm{a}$ & $577 \mathrm{~b}$ & $1287 \mathrm{~b}$ & $1932 \mathrm{~b}$ & $2049 \mathrm{ab}$ \\
\hline $\begin{array}{l}\text { Winter rye + hairy } \\
\text { vetch }\end{array}$ & $564 \mathrm{c}$ & $1156 \mathrm{c}$ & $1797 \mathrm{c}$ & $1916 \mathrm{~b}$ & $632 \mathrm{~b}$ & $1153 \mathrm{~b}$ & $1601 \mathrm{~b}$ & $1849 \mathrm{~b}$ \\
\hline No cover (control) & $841 \mathrm{a}$ & $1548 \mathrm{a}$ & $2235 \mathrm{a}$ & $2354 \mathrm{a}$ & 874 a & $1605 \mathrm{a}$ & $2339 a$ & $2485 \mathrm{a}$ \\
\hline Winter rye & $509 \mathrm{~b}$ & $992 \mathrm{~b}$ & $1659 \mathrm{a}$ & $1910 \mathrm{a}$ & $639 \mathrm{~b}$ & $1274 \mathrm{a}$ & $2091 \mathrm{a}$ & $2360 \mathrm{a}$ \\
\hline Hairy vetch & $553 \mathrm{~b}$ & $1084 \mathrm{ab}$ & $1828 \mathrm{a}$ & $2122 \mathrm{a}$ & $544 \mathrm{c}$ & $1122 \mathrm{~b}$ & 1953 a & 2209 a \\
\hline $\begin{array}{l}\text { Winter rye + hairy } \\
\text { vetch }\end{array}$ & $499 \mathrm{~b}$ & $995 \mathrm{~b}$ & $1672 \mathrm{a}$ & $1930 \mathrm{a}$ & $550 \mathrm{c}$ & $1135 \mathrm{~b}$ & 1954 a & $2231 \mathrm{a}$ \\
\hline No cover (control) & $634 \mathrm{a}$ & $1195 \mathrm{a}$ & $1837 \mathrm{a}$ & $2089 \mathrm{a}$ & $706 \mathrm{a}$ & $1340 \mathrm{a}$ & $2141 \mathrm{a}$ & 2427 a \\
\hline
\end{tabular}

${ }^{2}$ Early-season SGDD calculated from date of planting to 18 July in 2008 and 2 July in 2009. Date of planting was $\approx 16$ June in 2008 and $\approx 1$ June in 2009.

${ }^{y}$ Midseason SGDD calculated from date of planting to 15 Aug. in 2008 and 31 July in 2009.

${ }^{\mathrm{x}}$ Late-season SGDD calculated from date of planting to 26 Sept. in 2008 and 11 Sept. in 2009.

wTotal season SGDD calculated from date of planting to 30 Oct. in 2008 and 2009.

vAny two means within a column for 2008 and 2009 not followed by the same letter are different using Fisher's protected least significant difference $(P \leq 0.05)$. Different study years were compared using a separate analysis of variance. highest for the hairy vetch treatments at both sites and study years (data not shown). The hairy vetch treatments necessitated the most person hours resulting from continued regeneration of the biomass after the rolling event, which required subsequent hand cutting. Total person hours in the hairy vetch ranged from 12 to $14 \mathrm{~h} /$ season in 2008 to 19 to $20 \mathrm{~h} /$ season in 2009. Total person hours required for weeding the no-cover control treatments ranged from 10 to $12 \mathrm{~h} /$ season at both Lamberton and $\mathrm{St}$. Paul in both years, whereas the winter rye ( 0 to $3 \mathrm{~h} /$ season) and the WR/HV mixture ( 0 to $3 \mathrm{~h} /$ season) required 12 to 7 less person $\mathrm{h} /$ season to remove weeds. However, at Lamberton in 2009 , infestation of perennial weeds in the winter rye and WR/HV mixture plots necessitated frequent hand control $(11 \mathrm{~h} /$ season $)$ to limit competition with vegetables.

\section{Discussion}

Winter rye and hairy vetch cover crops can provide numerous benefits to a no-tillage, organic system (Sustainable Agriculture Network, 1998). In this study, we evaluated a tractor-mounted roller-crimper (Ashford and Reeves, 2003; NRCS Soil Quality Institute, 2002) for suppression of winter cover crops in organic vegetable systems. We found the anthesis growth stage to be an effective time to end a winter rye cover crop using a rollercrimper, which confirms other research (Ashford and Reeves, 2003; Mirsky et al., 2009). The roller was not an effective tool for ending hairy vetch at the vegetative growth stage that corresponded with winter rye anthesis (5\% to $10 \%$ bloom). In Pennsylvania, Mischler et al. (2010) reported that hairy vetch was most effectively ended at the early pod set but because this stage would occur too late in the growing season in Minnesota, hairy vetch termination did not take place at the ideal termination stage. Also, delaying rolling until winter rye reached anthesis resulted in shifting the vegetable planting dates to 2 to 5 weeks after recommended planting

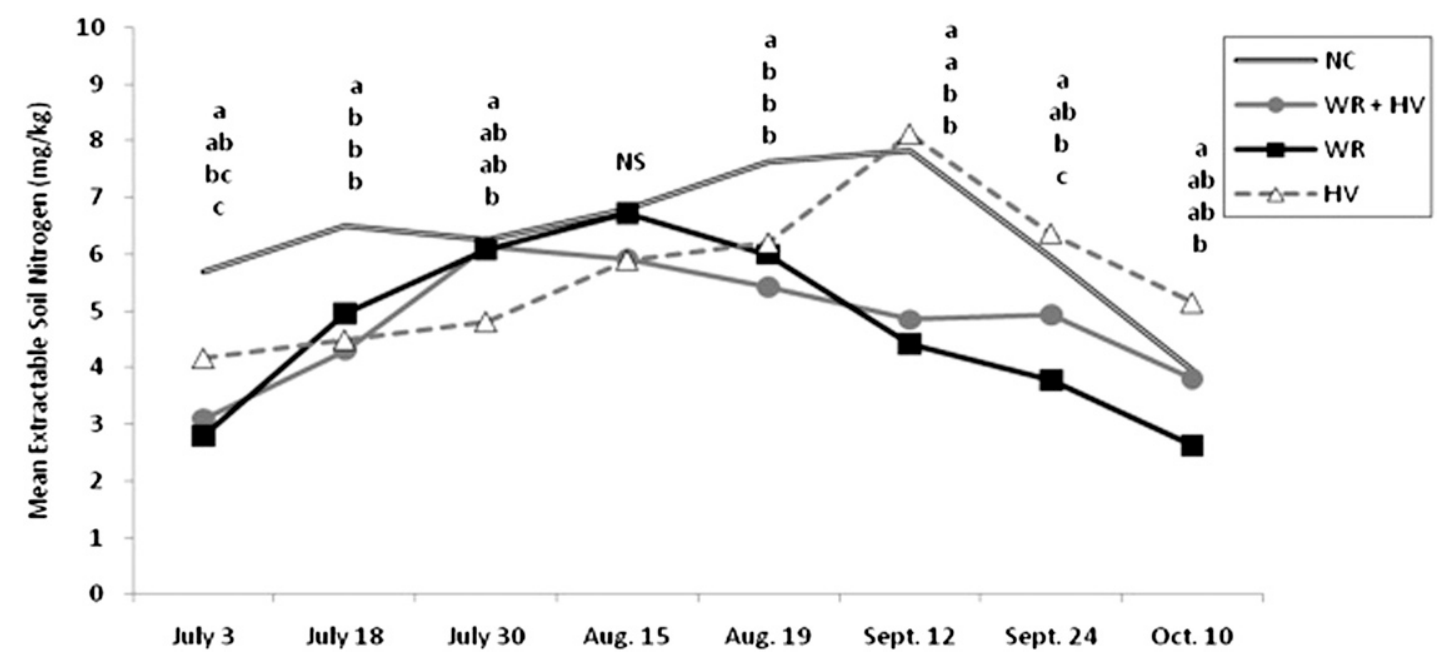

Fig. 1. Total extractable soil nitrogen $(\mathrm{N})\left(\mathrm{NH}_{4}{ }^{+}+\mathrm{NO}_{3}{ }^{-}\right)$by $\mathrm{NC}$ (no cover), WR $+\mathrm{HV}$ (mixture), WR (winter rye), and $\mathrm{HV}$ (hairy vetch) treatments in the top 15.2 $\mathrm{cm}$ of the soil profile at St. Paul, MN, 2008. Plots were fertilized with fish fertilizer on 3 July and 18 July. Mean separation within date by Fisher's protected least significant difference $(P \leq 0.05)$. 


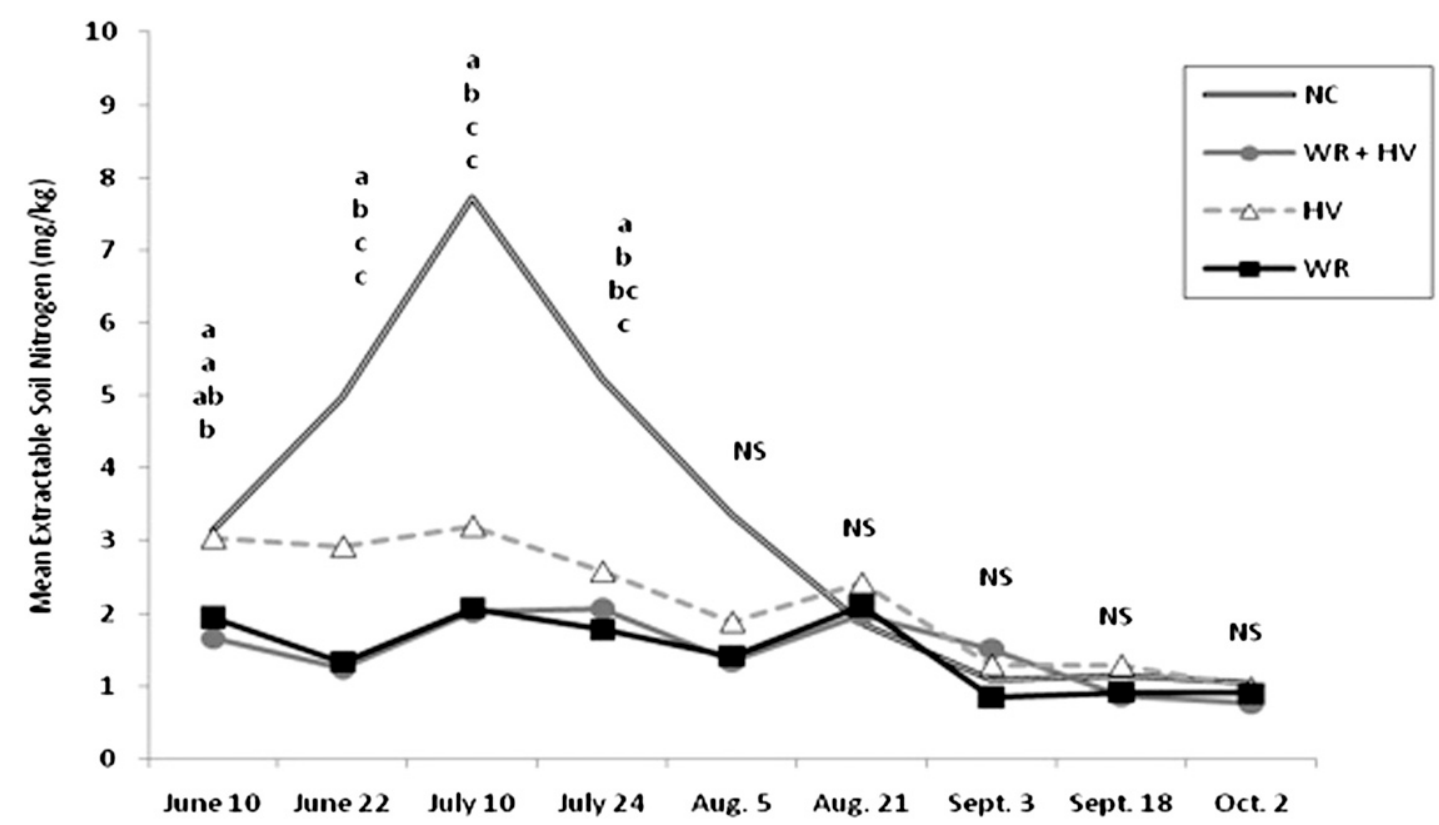

Fig. 2. Total extractable soil nitrogen ( $\mathrm{N}$ ) $\left(\mathrm{NH}_{4}{ }^{+}+\mathrm{NO}_{3}{ }^{-}\right.$) by $\mathrm{NC}$ (no cover), $\mathrm{WR}+\mathrm{HV}$ (mixture), WR (winter rye), and $\mathrm{HV}$ (hairy vetch) treatments in the top 15.2 $\mathrm{cm}$ of the soil profile at St. Paul, MN, 2009. Fish fertilizer was applied on 29 June and 7 July and composted turkey manure was applied on 13 July. Mean separation within date by Fisher's protected least significant difference $(P \leq 0.05)$.

dates in Minnesota, according to Fritz (2010), and this likely reduced yields.

The winter rye and WR/HV mixture, and to a lesser extent hairy vetch, were effective at reducing annual weed populations throughout the growing season compared with the hand-weeded no-cover control; however, marketable and total yield of tomato and zucchini were consistently lowered in all cover crops compared with the no-cover control. Marketable yield losses from using winter annual cover crops were similar to other research investigating summer squash (Walters and Young, 2008), bell pepper (Díaz-Pérez et al., 2008), and tomatoes (Roberts and Cartwright, 1991; Wahle and Masiunas, 2002; Yaffa et al., 2000) planted into rye and/or hairy vetch mulch. Bell pepper yield responses to winter cover crop mulch were variable by location and study year.

Adapting this system to cool climate regions presents its own unique challenges and marketable yield losses may be the result of several factors such as reduced SGDD, nutrient immobilization, plant mortality resulting from insect pressure, and competition with cover crops, weed competition, and/or allelopathy.

Soil temperatures, and hence accumulated SGDD, were lowered in the cover crop treatments at St. Paul and Lamberton early in the growing season in both study years. Walters and Young (2008) found that no-tillage plots with killed winter rye lowered soil temperatures compared with a no-cover control, which resulted in delayed maturity of zucchini and reduced yields (NeSmith et al., 1994; Walters et al., 2005). Low soil root-zone temperatures early in the season can negatively impact root and shoot growth (Gosselin and Trudel, 1985; Tachibana, 1982), nutrient uptake (Smart and Bloom, 1991; Tachibana, 1982), and water translocation (Ahn et al., 1999; Allen and Ort,
2001). Bell pepper, squash, and tomato are all known to be sensitive to low soil temperatures (Saltveit and Morris, 1990) and their development would likely be slowed by delayed accumulation of SGDD. Greater SGDD earlier in the season likely favored more vigorous growth of vegetable crops in the no-cover control as opposed to the cover crop treatments. The difference was more noticeable at early and midseason, which likely affected the growth and development of the vegetable crops throughout the duration of the season. However, temperature alone may not account for the degree of variation we observed in marketable yield between cover crop treatments. Teasdale and Abdul-Baki (1995), for example, found no effect of soil temperature in comparing total tomato yields among black plastic, bare soil, and hairy vetch mulch when this system was studied in Maryland. Vegetable plants grown in the cover crop mulches at St. Paul and Lamberton remained stunted and variably chlorotic throughout the season even when soil temperatures returned to within the optimum range $\left(20\right.$ to $\left.30^{\circ} \mathrm{C}\right)$ for summer vegetables at $\approx 4$ to 5 WAR in 2008 and 2009. Compared with the no-cover control, vegetables grown in the cover crops never regained growth or vigor as the season progressed.

Low soil $\mathrm{N}$ concentrations (less than 10 $\mathrm{mg} \cdot \mathrm{kg}^{-1} \mathrm{~N}$ ) likely contributed to reduced marketable yield of vegetables grown in winter cover crop mulches and the chlorotic appearance of vegetable plants. Before cover crop rolling and vegetable planting, a significant amount of $\mathrm{N}$ may have been taken up by the cover crops and/or immobilized by microbial degradation as evidenced by large discrepancies between biweekly soil $\mathrm{N}$ sampling and pre-season soil testing. Despite additional fertilization throughout the growing season, soil $\mathrm{N}$ concentrations were consistently below 20 to $25 \mathrm{mg} \cdot \mathrm{kg}^{-1} \mathrm{NO}_{3}-\mathrm{N}$, an amount identified by Heckman et al. (2002) as a critical pre-sidedress level for cabbage, which has similar nutrient requirements to most vegetables investigated in this study (Hartz, 2003; Rosen and Eliason, 2005). In our study, levels of soil $\mathrm{N}$ in cover crop treatments were similar to those found by Hoyt and Mikkelson (1991), who observed consistently low levels of soil $\mathrm{N}$ (less than $10 \mathrm{mg} \cdot \mathrm{kg}^{-1} \mathrm{~N}$ to less than $2 \mathrm{mg} \cdot \mathrm{kg}^{-1} \mathrm{~N}$ ) at $102-$ to $127-\mathrm{cm}$ soil depths. Soil $\mathrm{N}$ accumulation by growing cover crops, especially winter rye (Feyereisen et al., 2006; Ranells and Wagger, 1997), and microbial immobilization of $\mathrm{N}$ during decomposition of high carbon residues after rolling likely contributed to low N levels during the 2008 and 2009 growing seasons. Additionally, under heavier residues with higher moisture and lowered temperatures such as winter rye and the WR/HV mixture, soils could potentially be less aerobic and have less available $\mathrm{N}$ than the no-cover control (Doran and Smith, 1991). No-cover control plots had equally low soil N, especially at Lamberton in 2009, but produced superior marketable yields. The absence of cover crop residues, which accumulated residual soil $\mathrm{N}$, and vigorous growth of vegetable crops might be an explanation for this observation. Additionally, shallow sampling depth and interrow sampling sites where no fertilization occurred may have resulted in low soil $\mathrm{N}$ concentrations, although samples at shallower depths often correlate well with levels deeper in the soil profile (Hartz and Breschini, 2000).

High rates of vegetable transplant mortality, especially in the hairy vetch at Lamberton and the winter rye and $\mathrm{WR} / \mathrm{HV}$ mixture at St. Paul, were another likely contributor to lower vegetable yields in 2008. Vegetable plants 
replaced at 2 and 4 WAR would have delayed yield onset compared with the first planting. Primary causes of plant mortality included poor transplant planting, cutworm (Agrotis, Amathes, Peridroma, Prodenia spp.) predation, or cover crop competition. Cutworms were observed in the cover crop treatments during inspection of killed transplants. Successful transplanting was complicated by high rates of cover crop mulch during planting, which could have limited adequate soil to root contact in all environments and years. Despite adequate pest control, cutworm predation was localized in some areas, especially on field perimeters, which have been found to be problematic in no-till agriculture (Fleischer, 2000).

Annual weed density remained low in the winter rye and $\mathrm{WR} / \mathrm{HV}$ mixture treatments and did not appear to negatively influence vegetable yields at St. Paul in either year. Annual weed density at Lamberton in the cover crop treatments, resulting from variable stands of winter rye alone and in the WR/HV mixture, may have contributed to lower vegetable crop yields in both study years. Although weed density was also reduced in the hairy vetch treatment compared with the no-cover control, less overall soil coverage and higher light transmittance through the mulch resulted in greater weed pressure, which may have contributed to reduced yields (Teasdale and Daughtry, 1993). This would suggest that hairy vetch provided adequate early-season weed suppression during spring biomass accumulation, but the weed-suppressive ability of the mulch decreased as the season progressed and the mulch degraded (Teasdale and Mohler, 1993). Higher populations of annual weeds later in the season in the hairy vetch treatment at both sites and study years may have contributed to lower vegetable yields. Perennial weed density at Lamberton in all cover crop treatments in both study years likely contributed to lower marketable yields in 2008 and 2009. Winter-seeded cover crops planted for one season are usually not effective at reducing perennial weed density (Fisk et al., 2001; Teasdale et al., 2007).

Allelopathic interference may have contributed to reduced marketable yields within winter annual cover crop plots, especially those with winter rye. Allelopathic compounds in winter rye (Barnes and Putnam, 1983) and, to a lesser extent, hairy vetch (White et al., 1989) can negatively impact the growth and development of small-seeded crops and weedy species (Burgos and Talbert, 2000), although transplants with vigorous root systems are usually less susceptible to these chemicals (Morse, 1995). Transplants at St. Paul and Lamberton, in both years, were planted into rye residue immediately after rolling, although mature residues are usually less allelopathic than rye seedlings (Sustainable Agriculture Network, 1998). Smeda and Weller's (1996) results suggested no apparent effect of allelopathy on tomatoes transplanted into rye compared with plots with no rye. However, Walters and Young (2008) surmised that significant yield reductions of zucchini were likely the result of allelopathy of rye residues.

\section{Conclusion}

Our data showed that the winter cover crops, winter rye and hairy vetch, demonstrated excellent potential for non-herbicidal management of annual weeds in organic vegetable production in the upper midwest United States. However, organic no-tillage vegetable production using winter cover crops presents unique implementation challenges in cool, northern states where growing seasons are short and low soil temperatures can reduce crop growth. Rolled winter rye and hairy vetch lowered SGDD accumulation into late June in both study years in the cover crop treatments. Combining some form of moderate tillage such as strip tillage with high residue cover crops in cool-season states may adequately warm the soil for vegetable production, which has seen some success in field trials (Delate et al., 2008; Hoyt, 1999). In addition, winter-seeded cover crops lowered extractable soil $\mathrm{N}$ below optimum levels, and additional fertilization at the time of planting and throughout the season was needed to overcome those deficits.

For the roller-crimper to be most effective at killing cover crops, early-maturing varieties of winter rye and hairy vetch need to be identified and integrated into this system to allow adequate growing degree-days for the cash crop. Additionally, more effective mechanical control must occur to prevent cover crop regrowth, as was observed with the hairy vetch treatment. Moreover, to reduce the risk of allelopathic interference by winter rye residues, the development of new winter hardy cover crop species adapted for the no-tillage system will increase the likelihood of this system being adopted in the upper Midwest.

\section{Literature Cited}

Abdul-Baki, A., J. Stommel, A. Watada, J. Teasdale, and R. Morse. 1996. Hairy vetch mulch favorably impacts yield of processing tomato. HortScience 31:338-340.

Ahn, S.J., Y.J. Im, G.C. Chung, B.H. Cho, and S.R. Suh. 1999. Physiological responses of graftedcucumber leaves and rootstock roots affected by low temperature. Sci. Hort. 81:397-408.

Allen, D.J. and D.R. Ort. 2001. Impacts of chilling temperatures on photosynthesis in warm-climate plants. Trends Plant Sci. 6:36-42.

Ashford, D. and W. Reeves. 2003. Use of a mechanical roller-crimper as an alternative kill method for cover crops. Amer. J. Altern. Agr. 18:37-45.

Barnes, J. and A. Putnam. 1983. Rye residues contribute weed suppression in no-tillage cropping systems. J. Chem. Ecol. 9:1045-1057.

Borowy, A. 2004. Effect of no-tillage and rye mulch on occurrence of weeds and aphids and on yields of cabbage, carrot and red beet. In: Bertschinger, L. and J.D. Anderson (eds.). Proc. XXVI Intl. Hort. Conf., Sustainability Hort. Systems in the 21st Century, Toronto Canada. Acta Hort. 638:147-149.

Brandsæter, L.O. and J. Netland. 1999. Winter annual legumes for use as cover crops in row crops in northern regions: I. Field experiments. Crop Sci. 39:1369-1379.
Burgos, N.R. and R.E. Talbert. 2000. Differential activity of allelochemicals from Secale cereale in seedling bioassays. Weed Sci. 48:302-310.

Clark, A.J., A. Decker, J. Meisinger, and M. McIntosh. 1997. Kill date of vetch, rye, and a vetch-rye mixture: II. Soil moisture and corn yield. Agron. J. 89:434-441.

Clark, S. and M. Panciera. 2002. Cover crop rolldown for weed suppression in no-till crop production. Fruit and vegetable crops research report. Univ. Kentucky Agr. Expt. Sta. p. 56-57.

Creamer, N. and S. Dabney. 2002. Killing cover crops mechanically: Review of recent literature and assessment of new research results. Amer. J. Altern. Agr. 17:32-40.

Dabney, S.M. 1998. Cover crop impacts on watershed hydrology. J. Soil Water Conserv. 53:207213.

Delate, K., C. Cambardella, and A. McKern. 2008. Effects of organic fertilization and cover crops on an organic pepper system. HortTechnology 18:215-226.

Dethier, B.E. and M.T. Vittum. 1967. Growing degree days in New York state. Cornell Univ. Agr. Exp. Sta. Bul. 1017:4.

Díaz-Pérez, J., J. Silvoy, S. Phatak, J. Ruberson, and R. Morse. 2008. Effect of winter cover crops and no-till on the yield of organically grown bell pepper (Capsicum annuum L.). In: Prange, R. and S. Bishop (eds.). Proc. XXVII IHC-S11 Sustainability through integrated and organic horticulture. Acta Hort. 767.

Dimitri, C. and C. Greene. 2002. Recent growth patterns in the U.S. organic foods market. Agr. Information Bul. AIB777.

Doran, J. and M. Smith. 1991. Role of cover crops in nitrogen cycling, p. 85-90. In: Hargrove, W.L. (ed.). Cover crops for clean water. Proc. Int. Conf., West Tennesse Exp. Sta., Jackson, MS, 9-11 Apr.

ERS-USDA. C. Greene. 2009. Organic production data sets. U.S. Department of Agr. Economic Res. Serv. 9 Sept. 2009. <http://www.ers.usda. gov/Data/Organic/>.

Feekes, W. 1941. De Tarwe en haar milieu. Vers. XVII Tech. Tarwe Comm, Groningen. p. 560 561.

Feyereisen, G.W., B.N. Wilson, G.R. Sands, J.S. Strock, and P.M. Porter. 2006. Potential for a rye cover crop to reduce nitrate loss in southwestern Minnesota. Agron. J. 98:1416-1426.

Fisk, J.W., O.B. Hesterman, A. Shrestha, J.J. Kells, R.R. Harwood, J.M. Squire, and C.C. Sheaffer. 2001. Weed suppression by annual legume cover crops in no-tillage corn. Agron. J. 93:319325.

Fleischer, S. 2000. Early season soil pests. Penn State College Agr. Sci. Entomol. 11 Nov. 2010. $<$ http://ento.psu.edu/extension/factsheets/earlyseason-soil-pests $>$.

Frans, R.E., R. Talbert, D. Marx, and H. Crowley. 1986. Experimental design and technique for measuring and analyzing plant response to weed control practices, p. 37. In: In: Camper, N. (ed.). Research methods in weed science. Southern Weed Sci. Soc., Champaign, IL.

Fritz, V. 2010. Planting the vegetable garden. Univ. Minnesota Ext. Serv. 11 Nov. 2010. $<$ http://www. extension.umn.edu/distribution/horticulture/ dg1422.html>.

Gosselin, A. and M. Trudel. 1985. Influence of root-zone temperature on growth, development and yield of cucumber plants cv. Toska. Plant Soil 85:327-336.

Hartz, T.K. 2003. The assessment of soil and crop nutrient status in the development of efficient fertilizer recommendations. Acta Hort. 627:231240. 
Hartz, T.K. and S. Breschini. 2000. Determining nitrogen requirements of lettuce through presidedress soil nitrate testing (PSNT). HortScience 35:452.

Heckman, J.R., T.F. Morris, J.T. Sims, J.B. Sieczka, U. Krogmann, P. Nitzsche, and R. Ashley. 2002. Presidedress soil nitrate test is effective for fall cabbage. HortScience 37:113117.

Hoffman, M., E. Regnier, and J. Cardina. 1993. Weed and corn (Zea mays) responses to a hairy vetch (Vicia villosa) cover crop. Weed Technol. 7:594-599.

Hoyt, G. 1999. Tillage and cover residue affects on vegetable yield. HortTechnology 9:351-358.

Hoyt, G. and R. Mikkelson. 1991. Soil nitrogen movement under winter cover crops and residues, p. 91-94. In: Hargrove, W.L. (ed.). Cover crops for clean water. Proc. Int. Conf., West Tennesse Exp. Stn., Jackson, MS, 9-11 Apr.

Hoyt, G., D. Monks, and T. Monaco. 1994 Conservation tillage for vegetable production. HortTechnology 4:129-135.

Kuratomi, M., D. Allan, and E. Dyck. 2004. Long term effects of crop management: Soil quality. Results from the VICMS study at the Southwest Research and Outreach Center, Lamberton, MN. 12 Dec. 2009. <http://swroc.coafes. umn.edu/organic/research/completed/vicmssoil. pdf $>$.

Lamarca, C.C. 1996. Stubble over the soil. The vital role of plant residue in soil management to improve soil quality. Am. Soc. Agron., Madison, WI.

Liebl, R., F.W. Simmons, L.M. Wax, and E.W. Stoller. 1992. Effect of rye (Secale cereale) mulch on weed control and soil moisture in soybean (Glycine max). Weed Technol. 6:838846.

Madden, N.M., J.P. Mitchell, W.T. Lanini, M.D. Cahn, E.V. Herrero, S. Park, S.R. Temple, and M. van Horn. 2004. Evaluation of conservation tillage and cover crop systems for organic processing tomato production. HortTechnology 14:243-250.

Masiunas, J.B. 2006. Rye as a weed management tool in vegetable cropping systems, p. 127-151. In: Singh, H.P., D.R. Batish, and R.K. Kohli (eds.). Handbook of sustainable weed management. Food Products Press, New York, NY.

MDA M. Moynihan. 2007. Experiences and outlook of Minnesota organic farmers. Minnesota Dept. Agr. 5 Jan. 2010.<http://www.mda.state. mn.us/news/publications/food/organicgrowing/ 2007orgsurvresults.pdf $>$.

Mills, D., B. Coffman, and J. Teasdale. 2002. Foliar disease in fresh-market tomato grown in differing bed strategies and fungicide spray programs. Plant Dis. 86:955-959.

Minnesota Climatology Working Group. 2009. Univ. Minnesota State Climatol. Office. 14 Dec. 2009. <http://climate.umn.edu/>.

Mirsky, S.B., W.S. Curran, D.A. Mortensen, M.R. Ryan, and D.L. Shumway. 2009. Control of cereal rye with a roller/crimper as influenced by cover crop phenology. Agron. J. 101:15891596.

Mischler, R., S.W. Duiker, W.S. Curran, and D. Wilson. 2010. Hairy vetch management for no-till organic corn production. Agron. J. 102: 355-362.

Morse, R. 1995. No-till, no-herbicide systems for production of transplanted broccoli, p. 113-116. In: Kingrey, W.L. and N. Buehring (eds.). Conservation-farming: A focus on water quality. Proc. 1995 Southern Reg. Conservation Tillage Sustainable Agr., Jackson, MS, 26-28 June.
Morse, R. 1999. No-till vegetable production-Its time is now. HortTechnology 9:373-379.

NDSU. 2010. Recommended chemical soil test procedures for the north central region. North Central Reg. Res. Publ. 221.

NeSmith, D., G. Hoogenboom, and D. McCracken. 1994. Summer squash production using conservation tillage. HortScience 29:28-30.

NRCS Soil Quality Institute. 2002. The knife roller (crimper): An alternative kill method for cover crops. Soil Quality Agron. Tech. Note 13.

Organic Farming Research Foundation. 2004. Fourth national organic farmers' survey: Sustaining organic farms in a changing organic marketplace. 5 Jan. 2010. <http://ofrf.org/publications/ pubs/4thsurvey_results.pdfs.

Phatak, S., J. Dozier, A. Bateman, K. Brunson, and N. Martini. 2002. Cover crops and conservation tillage in sustainable vegetable production. In: Santen, E. (ed.). Making conservation tillage conventional: Building a future on 25 years of research. Proc. 25th Annu. Southern Conservation Tillage Conf. Sustainable Agr. Auburn, AL, 24-26 June 2002. Special Rpt. 1. Alabama Agr. Expt. Stn. and Auburn Univ., AL.

Ranells, N. and M. Wagger. 1997. Nitrogen-15 recovery and release by rye and crimson clover cover crops. Soil Sci. Soc. Amer. J. 61:943948.

Riemens, M., R. Groeneveld, L. Lotz, and M. Kropff. 2007. Effects of three management strategies on the seedbank, emergence and the need for hand weeding in an organic system. Weed Res. 47:442-451.

Roberts, B.W. and B. Cartwright. 1991. Vegetable production with conservation tillage and raised beds. Southern Conservation Tillage Conf. Sustainable Agr. 72-76.

Rosen, C. and R. Eliason. 2005. Nutrient management for commercial fruit and vegetable crops in Minnesota. Univ. Minnesota Ext. Serv.

Saltveit, M.E., Jr and L.L. Morris. 1990. Overview on chilling injury of horticultural crops. In: Wang, C.Y. (ed.). Chilling injury of horticultural crops. CRC Press, Boca Raton, FL.

Sarrantonio, M. 1994. Northeast cover crop handbook. Soil health series. Rodale Inst., Kutztown, PA.

SAS Institute. 2009. SAS Inst., Cary, NC.

Schonbeck, M.W. and G.K. Evanylo. 1998. Effects of mulches on soil properties and tomato production. I. Soil temperature, soil moistures and marketable yield. J. Sustain. Agr. 13:55-81.

Sechtig, A. 1992. Nitrate in $2 \mathrm{M} \mathrm{KCl}$ soil extracts. QuikChem Method 12-107-04-1-B. Lachat Instruments, Milwaukee, WI.

Singer, J.W. 2008. Corn belt assessment of cover crop management and preferences. Agron. J. 100:1670-1672

Smart, D.R. and A.J. Bloom. 1991. Influence of root $\mathrm{NH}_{4}^{+}$and $\mathrm{NO}^{-}$content on the temperature response of net $\mathrm{NH}^{+}$and $\mathrm{NO}^{-}$uptake in chilling sensitive and chilling resistant Lycopersicon taxa. J. Expt. Bot. 42:331-338.

Smeda, R. and S. Weller. 1996. Potential of rye (Secale cereale) for weed management in transplant tomatoes (Lycopersicon esculentum). Weed Sci. 44:596-602.

Snapp, S., S. Swinton, R. Labarta, D. Mutch, J. Black, R. Leep, J. Nyiraneza, and K. O’Neil. 2005. Evaluating cover crops for benefits, costs and performance within cropping system niches. Agron. J. 97:322-332.

Sustainable Agriculture Network. 1998. Managing cover crops profitably. 2nd Ed. Sustainable Agr. Network Natl. Agr. Library, Beltsville, MD.
Switala, K. 1993. Ammonia (salicylate) in $2 \mathrm{M} \mathrm{KCl}$ soil extracts. QuikChem method 12-107-06-2A. Lachat Instruments, Milwaukee, WI.

Tachibana, S. 1982. Comparison of effects of root temperature on the growth and mineral nutrition of cucumber cultivars and figleaf gourd. J. Jpn. Soc. Hort. Sci. 51:299-308.

Teasdale, J. and C. Mohler. 2000. The quantitative relationship between weed emergence and the physical properties of mulches. Weed Sci. 48: 385-392.

Teasdale, J.R. and A.A. Abdul-Baki. 1995. Soil temperature and tomato growth associated with black polyethylene and hairy vetch mulches. J. Amer. Soc. Hort. Sci. 120:848-853.

Teasdale, J.R., C.E. Beste, and W.E. Potts. 1991. Response of weeds to tillage and cover crop residue. Weed Sci. 39:195-199.

Teasdale, J.R., C.B. Coffman, and R.W. Mangum. 2007. Potential long-term benefits of no-tillage and organic cropping systems for grain production and soil improvement. Agron. J. 99: 1297-1305.

Teasdale, J.R. and C.S.T. Daughtry. 1993. Weed suppression by live and desiccated hairy vetch. Weed Sci. 41:207-212.

Teasdale, J.R. and C.L. Mohler. 1993. Light transmittance, soil temperature, and soil moisture under residue of hairy vetch and rye. Agron. J. 85:673-680.

Triplett G., Jr. and W. Dick. 2008. No-tillage crop production: A revolution in agriculture! Agron. J. 100:S-153-S-165.

USDA. 1997a. United States standards for grades of tomatoes. Effective 1 Oct. 1991. Agr. Mktg. Serv., Washington, DC

USDA. 1997b. United States standards for grades of summer squash. Effective 6 Jan. 1984. Agr. Mktg. Serv., Washington, DC.

USDA. 2005. United States standards for grades of sweet peppers. Corrected and effective 17 Nov. 2005. Agr. Mktg. Serv., Washington, DC.

Villamil, M.B., G.A. Bollero, R.G. Darmody, F.W. Simmons, and D.G. Bullock. 2006. No-till corn/soybean systems including winter cover crops: Effects on soil properties. Soil Sci. Soc. Amer. J. 70:1936-1944.

Wahle, E.A. and J.B. Masiunas. 2002. The effect of spring planted cereal rye on the yield of fresh market vegetables. J. Veg. Crop Production 8: 123-132.

Walters, S.A., S.A. Nolte, and B.G. Young. 2005. Influence of winter rye and pre-emergence herbicides on weed control in no-tillage zucchini squash production. HortTechnology 15: 238-243.

Walters, S.A. and B. Young. 2008. Utility of winter rye living mulch for weed management in zucchini squash production. Weed Technol. 22: 724-728.

White, R.H., A.D. Worsham, and U. Blum. 1989. Allelopathic potential of legume debris and aqueous extracts. Weed Sci. 37:674-679.

Wyland, L., L. Jackson, W. Chaney, K. Klonsky, S. Koike, and B. Kimple. 1996. Winter cover crops in a vegetable cropping system: Impacts on nitrate leaching, soil water, crop yield, pests and management costs. Agr. Ecosyst. Environ. $56: 1-17$.

Yaffa, S., U.M. Sainju, and B.P. Singh. 2000. Fresh market tomato yield and soil nitrogen as affected by tillage, cover cropping and nitrogen fertilization. HortScience 35:1258-1262.

Yenish, J.P., A.D. Worsham, and A.C. York. 1996. Cover crops for herbicide replacement on notillage corn (Zea mays). Weed Sci. 10:815882. 